\title{
STUDY OF THE IMPACT OF MICROALBUMINURIA ON THE MORBIDITY AND MORTALITY OF THE ACUTE CORONARY SYNDROME IN DIABETIC PATIENTS DURING ICU ADDMISSION
}

\author{
M.E.G. Kamar', M.H. Assy ${ }^{1}$, Hatem M. Salem ${ }^{1}$, Mohamed S.S. Saad ${ }^{1}$ \& Nermin Raafat ${ }^{2}$ \\ ${ }^{1}$ Internal Medicine Department, Faculty of Medicine, Zagazig University, Egypt. \\ ${ }^{2}$ Medical Biochemistry Department, Faculty of Medicine, Zagazig University, Egypt.
}

\begin{abstract}
Background: Microalbuminuria (MA) is a well- known risk factor for coronary artery disease (CAD) in diabetics and non diabetics. It is associated with higher cardiovascular mortality. However, the impact of MA on the morbidity and mortality of the acute coronary syndrome (ACS) in diabetic patients is not definitively known and the relationship between the degree of albuminuria and outcome of ACS is unclear. Aim of the Work: To Study the morbidity and mortality of diabetic patients presenting with acute coronary symptoms in relation to presence of MA during ICU admission. Patient and Methods: This study was planned to evaluate the impact of MA on outcome of ACS in diabetics patients admitted to ICU in internal medicine department Zagazig University. The study included 80 patients with acute coronary syndrome 60 diabetics and 20 non diabetics. Patients were classified into four groups: Group (A): 20 ACS non diabetic patients with no albuminuria. Group (B): 20 ACS type 2 diabetic patients without albuminuria. Group (C): 20 ACS type 2 diabetic patients with MA. Group (D): 20 ACS type 2 diabetic patients with macroalbuminuria. Urinary albumin excretion rate was performed to all patients with ACS. They were followed up during their staying in the ICU for the occurrence of heart failure, pulmonary embolism, shock, arrithymia or death. Serum lipid profile and $\mathrm{HbA1c}$ were performed also for all patients. Results: Complications occurred more significantly in albuminuric patients with MA (70\%) and with macroalbuminuria $(65 \%)$ than non albuminuric patients $(20 \%) ;(\mathrm{P}<0.001)$. Complications also occurred more significantly in patients with HbA1c>7\%(69.7\%) than those with $\mathrm{HbA} 1 \mathrm{c}<7 \%(30.3 \%) ;(\mathrm{P}<0.001)$. Also complications occurred more significantly in patients with serum triglyceride $>150$ $\mathrm{mg} / \mathrm{dl}(78.4 \%)$ than those with serum triglyceride $<150 \mathrm{mg} / \mathrm{dl}(14 \%) ;(\mathrm{P}<0.001)$ and $\mathrm{LDL}>100 \mathrm{mg} / \mathrm{dl}(82.4)$ than those with $\mathrm{LDL}<100 \mathrm{mg} / \mathrm{dl}(15.3 \%) ;(\mathrm{P}<0.001)$. Conclusions: There is a significant prevalence of albuminuria in diabetic patients in comparison with non diabetic patients. Complications including life threatening disorder as arrhythmia, heart failure, shock and cardiac arrest occurred more significantly in diabetic albuminuric patients with ACS during admission to ICU. Complications occurred more significantly in patients with abnormal lipid profile especially patients with hypertriglyceridemia or LDL > 100mg/dl.

Keyword: Microalbuminuria, Cardiovascular disease, Acute Coronary Syndrome, Diabetes, Hypertriglyceridemia.
\end{abstract}

\section{INTRODUCTION}

M icroalbuminuria (MA) is a well- known risk factor for coronary artery disease (CAD) in diabetics and non diabetics. It is associated with higher cardiovascular mortality, especially in diabetics. However, there are few data linking angiographic severity of CAD to MA (1).

The presence of albuminuria is a powerful predictor of cardiovascular risk in patients with type 2 diabetes (T2D) and hypertension. In addition, multiple studies have shown that decreasing the level of albuminuria reduces the risk of adverse cardiovascular outcomes (2).

In most survival studied in non-insulin dependant diabetes mellitus (NIDDM), microalbuminuria predicts early mortality; in cross-section studies, it is associated with CAD morbidity (3).

MA was found to be an independent predictor for the presence and severity of CAD. A strong relationship between MA and the severity of CAD was reported by Deveci et al., (4).

However, the impact of MA on the morbidity and mortality of the acute coronary syndrome (ACS) in diabetic patients is not definitively known and the relationship between the degree of albuminuria and outcome of ACS is unclear.
The aim of this work is to Study the morbidity and mortality of diabetic patients presenting with acute coronary symptoms in relation to presence of MA during ICU admission.

\section{PATIENTS AND METHODS}

This study had been carried out in Internal Medicine Department, Cardiological Intensive Care Unite, and Biochemistry Department at Zagziag University Hospitals.

It included 80 patients with ACS: 60 diabetics and 20 non diabetics. Their ages ranged from 50 to 86 yrs old with mean \pm SD $59.7 \pm 8.7$ years and 40 of them are males and other 40 are females.

\section{Inclusion criteria:}

Patients who were diagnosed to have ACS were included in this study either diabetics or not.

\section{Exclusion criteria:}

Patient with renal disease, liver dysfunction, those receiving medication affecting kidney albumin excretion were exclude from this study.

Patients were classified into 4 groups:

Group (A): 20 ACS non diabetic patients with no albuminuria. Their age ranged from (45 -75) years. 
Group (B): 20 ACS type 2 diabetic patients without albuminuria Their age ranged from (4575) years.

Group (C): 20 ACS type 2 diabetic patients with MA. Their age ranged from (49-80) years.

Group (D): 20 ACS type 2 diabetic patients with macro albuminuria. Their age ranged from (4870) years.

All patients were subjected to the following:- Full history taking and detailed clinical examination with particular consideration on:

- Symptoms and sings of coronary heart disease.

- Estimation of BMI and waist /hip ratio.

- Routine laboratory investigations.

- Complete blood picture using sysmex S.F3000 automated analyzer.

- Liver and kidney function tests using Dimnsion E.S. chemical auto analyzer.

- Admission blood glucose level

- Urine analysis for detection of albuminuria.

- Serum uric acid.

- Cardiac enzyme CPKMB

- All patients have also

- ECG

- Plain X-ray chest

- Pelvi-abdominal ultrasonography.

- Specific laboratory investigations:

- Serum lipid profile (cholesterol triglycerides - LDL- HDL).

- HbAlc.

- Microalbumin in urine

- Creatinine in urine.

Principle of methods:

1. HbA1c measured by HbA1c kits (code, 11044, 11045 Bio systems).

After preparing the hemolysate, where the labile fraction is eliminated hemoglobins are retained by a cationic exchange resin. HbA1c is specifically eluted after washing away the hemoglobin $\mathrm{A} 1+\mathrm{b}$ fraction $1(\mathrm{HbA} 1 \mathrm{c})$, and is quantified by direct photometric reading at $415 \mathrm{~nm}$. The estimation of the relative concentration of $\mathrm{HbA} 1 \mathrm{c}$ is made by the measure of total hemoglobin concentration by direct photometric reading at $415 \mathrm{~nm}$.

2. Albuminuria: measured by microalbumin (code, 31324, 31924 Biosystem).

Albumin in the urine sample causes agglutination of the latex particles coated with anti-human albumin. The agglutination of the particles is proportional to the albumin concentration and can be measured by turbidimetry. After interpretation of the results of microalbumin in urine and creatinine in urine calculation of albumin creatinine ratio was done.
According to National Kidney Disease Program (NKDEP) urine albumin-to-creatinine ratio (UACR) in evaluating patients with T2D for kidney disease:

$\frac{\text { Urine Albumin }(\mathrm{mg} / \mathrm{dL})}{\text { Urine Creatinine }(\mathrm{g} / \mathrm{dL})}=\mathrm{UACR}$ in $\mathrm{mg} / \mathrm{g}$ Albumin excretion in $\mathrm{mg} / \mathrm{day}$ UACR is a ratio between two measured substances. Unlike a dipstick test for albumin, UACR is unaffected by variation in urine concentration.

According to NKDEP Albuminuria is a term that describes all levels of urine albumin. Microalbuminuria is a term used to describe urine albumin levels not detected by a dipstick test, i.e., $30 \mathrm{mg} / \mathrm{g}-300 \mathrm{mg} / \mathrm{g}$. Macroalbuminuria is sometimes used to describe albumin levels more than $300 \mathrm{mg} / \mathrm{g}$.

\section{RESULTS}

A total of 80 ACS patients $(60$ T2D and 20 non diabetics) were recruited for the study.

\section{1- Study of the demographic data and clinical characteristics among studied groups:}

Table (1) shows the demographic data among diabetics and non diabetics. The diabetic group comprised 30 women and 30 men while the non diabetic group comprised 8 women and 12 men, the sex distribution didn't differ significantly between the two groups. The age rang in the diabetic group was (45-75) years while it was in non diabetic group (45-70), the mean age in diabetics was $59.7 \pm 8.7$ while it was in non diabetics $57.8 \pm 8$. The mean age didn't differ significantly between the two groups. There was non-significance between the two groups of the study as regards body weight (BW), height and body mass index (BMI).

2- Study of the biochemical parameters between the 2 groups:

Table (2) shows the comparison between the 2 groups of the study as regards their serum lipid profile (total cholesterol, triglycerides, low density of lipoprotein [LDL], high density of lipoprotein [HDL]) $(\mathrm{mg} / \mathrm{dl})$. Serum total cholesterol was significantly higher in diabetics then non diabetic $(p<0.05)$ while LDL, HDL didn't differ significantly between the two groups. Serum triglycerides were none significantly higher in the diabetics than in the non diabetes. On the other hand, admission blood glucose was significantly higher in the diabetics than in the non diabetics $(p<0.001)$. The same as HbA1c which was significantly higher in diabetics than the non diabetics $(\mathrm{p}<0.001)$. Also, the cardiac enzymes (CPK-MB) was non significantly different between the two groups ( $\mathrm{p}$ $>0.05$ ). Albuminuria expressed by (Alb /cr) ratio was significantly higher in the diabetic group in 
comparison with the non diabetic group $(\mathrm{p}<$ $0.001)$.

3- Study of the relation between albuminuria and outcome of ACS patients admitted to ICU:

Table (3) shows the outcome was assessed as the occurrence of any complications requiring assistance or death. These complications included life threatening conditions as arrhythmia, heart failure, shock and cardiac arrest. Complications occurred more significantly in the albuminuric patients with microalbuminuria (70\%) and with macroalbuminuria $(65 \%)$ then non albuminuric patients $(20 \%) \quad(\mathrm{p}<0.001)$. Complications occurred more significantly in MA patients (70\%) than non- microabluminuric patients (20\%) (p $<0.001$ ). Also, in the relation between MA and outcome there were more significantly in macroalbuminuric patients $(65 \%)$ than non macroalbuminuric patients $(20 \%)(\mathrm{p}<0.001)$.

Figure (1) shows relation between albuminuria and outcome by general linear general linear model (GLM). Complications occurred more significantly with increasing levels of albuminuria.

4- Study of the relation between HbA1C level and outcome of ACS patients admitted to ICU:

Table (4) shows the relation between $\mathrm{HbA1C}$ level and outcome. Complications occurred more significantly in patients with $\mathrm{HbA1C}>7 \%(69.7 \%)$ than those with $\mathrm{HbA1C}<7 \%$ (30.3\%); ( $\mathrm{p}<0.001)$. Figure (2) Bar chart shows the relation between $\mathrm{HbA1C}$ and outcome. Figure (3) shows the relation between $\mathrm{HbA} 1 \mathrm{C}$ and outcome by GLM General Linear Model. There were complications occurred more significantly in patients with higher levels of HbA1C than those with lower levels of HbA1C $(\mathrm{F}=7.6 ; \mathrm{p}>0.05)$.

5- Relation between serum lipid profile level $\mathrm{mg} / \mathrm{dl}$ and outcome of ACS patients admitted to ICU:
Table (4) shows that the complications occurred more significantly in patients with serum triglycerides $>150 \mathrm{mg} / \mathrm{dl} 78.4 \%$ than those with triglycerides $<150$ $\mathrm{mg} / \mathrm{dl} 14 \%$ with ( $\mathrm{p}<0.001)$. As regards, the relation of LDL to outcome, there were more significantly in patients with LDL $>100(\mathrm{mg} / \mathrm{dl})(82.4 \%)$ than those with $\mathrm{LDL}<100(\mathrm{mg} / \mathrm{dl})(15.3 \%)$ with $(\mathrm{p}<0.001)$. While the relation of HDL to outcome, there was non-significant relation in patients with HDL $<40$ for male $<50$ for female $(43.5 \%)$ than those with HDL $>40$ for male and $>50$ for female $(27.3 \%)$ with $(\mathrm{p}>$ $0.05)$.

6- Study of the relation in between risk factors of coronary heart disease in type 2 diabetics:

Table (5) showed that there was non significant relation between serum triglycerides $>150 \mathrm{mg} / \mathrm{dl}$ and MA. As regards, there was positive significant relation between LDL $>100 \mathrm{mg} / \mathrm{dl}$ and MA, but we found a non-significant relation between abnormal HDL level and albuminuria. Also, there was a nonsignificant relation between BMI and outcome $(\mathrm{P}>0.05)$ as shown in table (6). There was nonsignificant positive relation between $\mathrm{HbA} 1 \mathrm{C}$ and levels of albuminuria by this diagram. As regards, relation between albuminuria and lipid profile $(\mathrm{mg} / \mathrm{dl})$ Figure (4). Also, There were non-significant correlation between $\mathrm{HbA1c}$ and (triglycerides, LDL and HDL) levels $(\mathrm{P}>0.05)$ Figure $(\mathbf{5 , 6 , 7})$.

7- Study the relation between Weight ratio and outcome:

There was non-significance in studying the relation between Weight ratio and outcome (P=NS) Figure (8). While our finding found the prevalence of complications among ACS patients admitted to intensive care unit (ICU); this diagram shows that the number of not complicated cases was 50 $(62.5 \%)$ and number of complicated cases was 30 (37.5\%) as shown in Figure (9)

Table (1): Demographic data among diabetics and non diabetics patients admitted to ICU with ACS

\begin{tabular}{|c|c|c|c|c|c|c|}
\hline & \multicolumn{2}{|c|}{$\begin{array}{l}\text { Diabetics } \\
(\mathrm{n}=60)\end{array}$} & \multicolumn{2}{|c|}{$\begin{array}{l}\text { Non diabetics } \\
\quad(\mathbf{n}=\mathbf{2 0})\end{array}$} & $t$ & $p$ \\
\hline $\begin{array}{l}\text { Age (years) } \\
\mathrm{X} \pm \text { SD } \\
\text { Range }\end{array}$ & \multicolumn{2}{|c|}{$\begin{array}{c}59.7 \pm 8.7 \\
(45-75)\end{array}$} & \multicolumn{2}{|c|}{$\begin{array}{l}57.8 \pm 8 \\
(45-70)\end{array}$} & 0.885 & NS \\
\hline Gender & No & $\%$ & No & $\%$ & & \\
\hline $\begin{array}{l}\text { Male } \\
\text { Female }\end{array}$ & $\begin{array}{l}30 \\
30\end{array}$ & $\begin{array}{l}50.0 \\
50.0\end{array}$ & $\begin{array}{c}12 \\
8\end{array}$ & $\begin{array}{l}60.0 \\
40.0\end{array}$ & 0.6 & NS \\
\hline $\begin{array}{l}\text { BW } \\
\mathrm{X} \pm \mathrm{SD}\end{array}$ & \multicolumn{2}{|c|}{$82 \pm 25.2$} & \multicolumn{2}{|c|}{$91.4 \pm 33.1$} & -1.311 & NS \\
\hline $\begin{array}{l}\text { Height (m) } \\
X \pm \text { SD }\end{array}$ & \multicolumn{2}{|c|}{$170.0 \pm 77.9$} & \multicolumn{2}{|c|}{$162.1 \pm 9.1$} & 0.450 & NS \\
\hline $\begin{array}{l}\text { BMI } \\
X \pm \text { SD }\end{array}$ & \multicolumn{2}{|c|}{$33.9 \pm 7.3$} & \multicolumn{2}{|c|}{$35.9 \pm 10.0$} & 0.924 & NS \\
\hline
\end{tabular}

Bw: body weight

BMI: body mass index NS: non-significant $p>0.05$ 
Table (2): Comparison between the two groups of study as regards their laboratory investigations (e.g., Blood glucose level, HbA1c, serum lipid profile, Cardiac enzyme [CPK-MB] and Albuminuria which expressed by $[\mathrm{Alb} / \mathrm{cr}]$ ratio)

\begin{tabular}{|c|c|c|c|c|}
\hline Variable & $\begin{array}{l}\text { Diabetics } \\
(\mathrm{n}=60)\end{array}$ & $\begin{array}{l}\text { Non diabetics } \\
\quad(\mathbf{n}=\mathbf{2 0})\end{array}$ & $t$ & $p$ \\
\hline $\begin{array}{l}\text { Admission blood glucose (mg/dl) } \\
X \pm S D\end{array}$ & $223.6 \pm 101.8$ & $132.2 \pm 33.9$ & 3.9 & $<0.001$ \\
\hline $\begin{array}{l}\text { HbA1c (\%) } \\
X+S D\end{array}$ & $7.2 \pm 1.8$ & $5.1 \pm 8.7$ & 5.2 & $<0.001$ \\
\hline $\begin{array}{l}\text { Total Cholesterol (mg/dl) } \\
X+S D\end{array}$ & $195.0 \pm 36.6$ & $168.0 \pm 48.2$ & -2.3 & $<0.05$ \\
\hline $\begin{array}{l}\text { Triglycerides (mg/dl) } \\
\mathrm{X}+\mathrm{SD}\end{array}$ & $197.9 \pm 85.8$ & $136 \pm 56.1$ & 0.37 & NS \\
\hline $\begin{array}{l}\text { LDL (mg/dl) } \\
X+S D\end{array}$ & $113.1 \pm 30.6$ & $103.1 \pm 30.8$ & -0.9 & NS \\
\hline $\begin{array}{l}\text { HDL (mg/dl) } \\
X+S D\end{array}$ & $36.9 \pm 20.5$ & $35.3 \pm 8.7$ & 0.08 & NS \\
\hline $\begin{array}{l}\text { CPK-MB } \\
X+S D\end{array}$ & $365+350$ & $394+547$ & -0.2 & NS \\
\hline $\begin{array}{l}\text { Albuminuria } \\
X+S D\end{array}$ & $331.6 \pm 392.8$ & $20.9 \pm 6.0$ & 3.5 & $<0.001$ \\
\hline
\end{tabular}

Table (3): Relation between albuminuria and outcome in ACS patients admitted to ICU

\begin{tabular}{|c|c|c|c|c|c|c|}
\hline & \multicolumn{2}{|c|}{$\begin{array}{c}\text { Not Complicated } \\
(\mathrm{n}=45)\end{array}$} & \multicolumn{2}{|c|}{$\begin{array}{c}\text { Complicated } \\
(\mathrm{n}=35)\end{array}$} & \multirow[t]{2}{*}{$\chi^{2}$} & \multirow[t]{2}{*}{$p$} \\
\hline & No & $\%$ & No & $\%$ & & \\
\hline $\begin{array}{r}\text { No albuminuria } \\
(\mathrm{n}=40)\end{array}$ & 32 & 80.0 & 8 & 20.0 & \multirow{3}{*}{18.4} & \multirow{3}{*}{$<0.001$} \\
\hline $\begin{array}{c}\text { Microalbuminuria } \\
(\mathrm{n}=20)\end{array}$ & 6 & 30.0 & 14 & 70.0 & & \\
\hline $\begin{array}{c}\text { Macroalbuminuria } \\
(\mathrm{n}=20)\end{array}$ & 7 & 35.0 & 13 & 65.0 & & \\
\hline
\end{tabular}

Table (4): Relation of HBA1c, serum triglycerides, LDL, and HDL to outcome in ACS patients admitted to ICU

\begin{tabular}{|c|c|c|c|c|c|c|c|}
\hline & \multicolumn{2}{|c|}{ Not Complicated } & \multicolumn{2}{|c|}{ Complicated } & \multirow{2}{*}{$\chi^{2}$} & \multirow{2}{*}{$p$} \\
\hline & & No & $\%$ & No & $\%$ & & \\
\hline $\begin{array}{l}\text { HbA1c } \\
\qquad \begin{array}{r}(\mathrm{n}=44) \\
(\mathrm{n}=36)\end{array}\end{array}$ & $\begin{array}{l}<7 \% \\
>7 \%\end{array}$ & $\begin{array}{c}(\mathrm{n}=47) \\
34 \\
13\end{array}$ & $\begin{array}{l}72.3 \\
27.7\end{array}$ & $\begin{array}{c}(\mathrm{n}=33) \\
10 \\
23\end{array}$ & $\begin{array}{l}30.3 \\
69.7\end{array}$ & 0.138 & $<0.001$ \\
\hline $\begin{array}{l}\text { Triglycerides } \\
\qquad \begin{array}{l}(\mathrm{n}=43) \\
(\mathrm{n}=37)\end{array}\end{array}$ & $\begin{array}{l}(\mathrm{mg} / \mathrm{dl}) \\
<150 \\
>150\end{array}$ & $\begin{array}{c}(\mathrm{n}=45) \\
37 \\
8\end{array}$ & $\begin{array}{l}86.0 \\
21.6\end{array}$ & $\begin{array}{c}(\mathrm{n}=35) \\
6 \\
29\end{array}$ & $\begin{array}{l}14.0 \\
78.4\end{array}$ & 33.5 & $<0.001$ \\
\hline $\begin{array}{r}\text { LDL }(\mathrm{mg} / \mathrm{dl}) \\
(\mathrm{n}=46) \\
(\mathrm{n}=34)\end{array}$ & $\begin{array}{l}<100 \\
>100\end{array}$ & $\begin{array}{c}(\mathrm{n}=45) \\
39 \\
6\end{array}$ & $\begin{array}{l}84.7 \\
17.6\end{array}$ & $\begin{array}{c}(\mathrm{n}=35) \\
7 \\
28\end{array}$ & $\begin{array}{l}15.3 \\
82.4\end{array}$ & 35.8 & $<0.001$ \\
\hline $\begin{array}{r}\text { HDL }(\mathrm{mg} / \mathrm{dl}) \\
(\mathrm{n}=11) \\
(\mathrm{n}=69)\end{array}$ & $\begin{array}{l}>40 \\
<50\end{array}$ & $\begin{array}{c}(\mathrm{n}=47) \\
8 \\
39\end{array}$ & $\begin{array}{l}72.7 \\
56.5\end{array}$ & $\begin{array}{c}(\mathrm{n}=33) \\
3 \\
30\end{array}$ & $\begin{array}{l}27.3 \\
43.5\end{array}$ & 1.0 & $>0.05$ \\
\hline
\end{tabular}




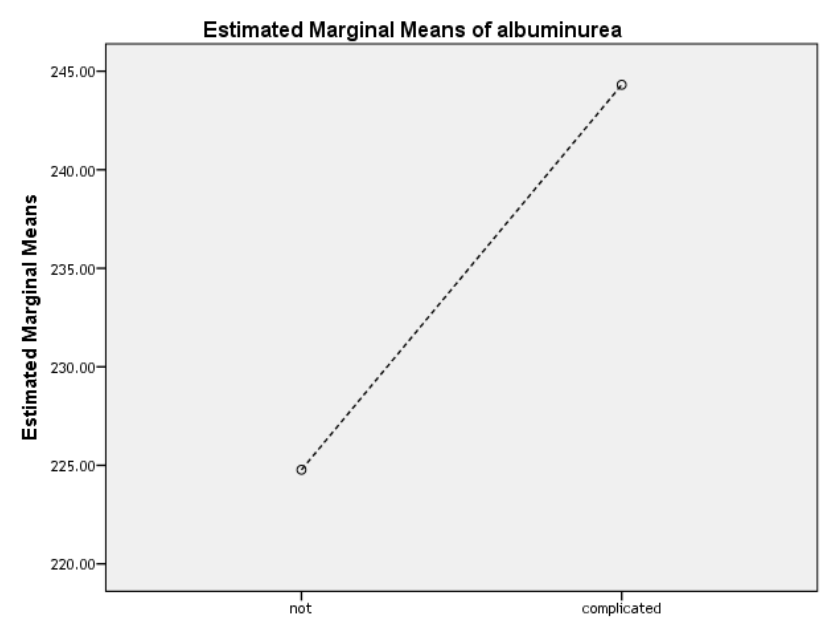

Figure (1): Relation between albuminuria an outcome by General Linear Model (GLM)

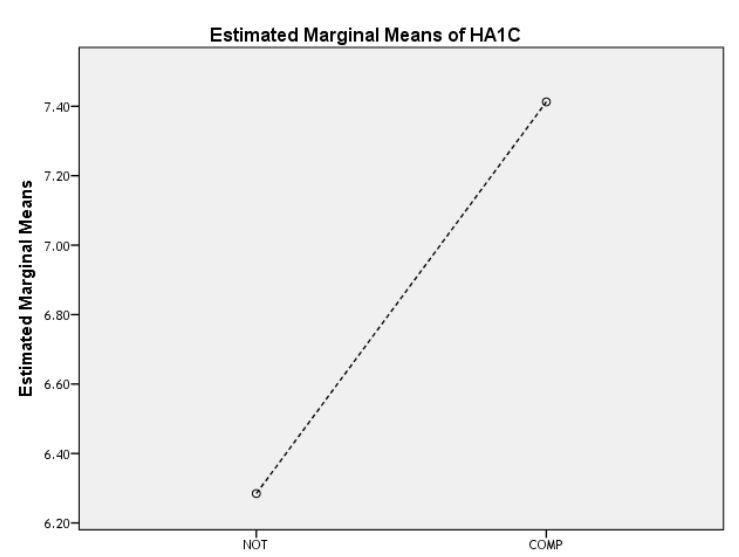

(GLM) $\quad \mathrm{F}=7.6 \quad \mathrm{P}=<0.05$

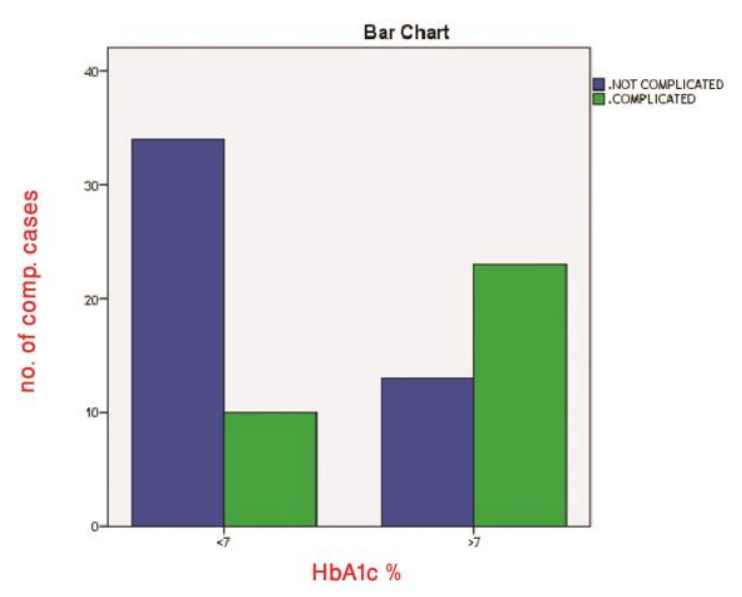

Figure (2): Bar chart showing the relation between $\mathrm{HbAlc}$ and outcome

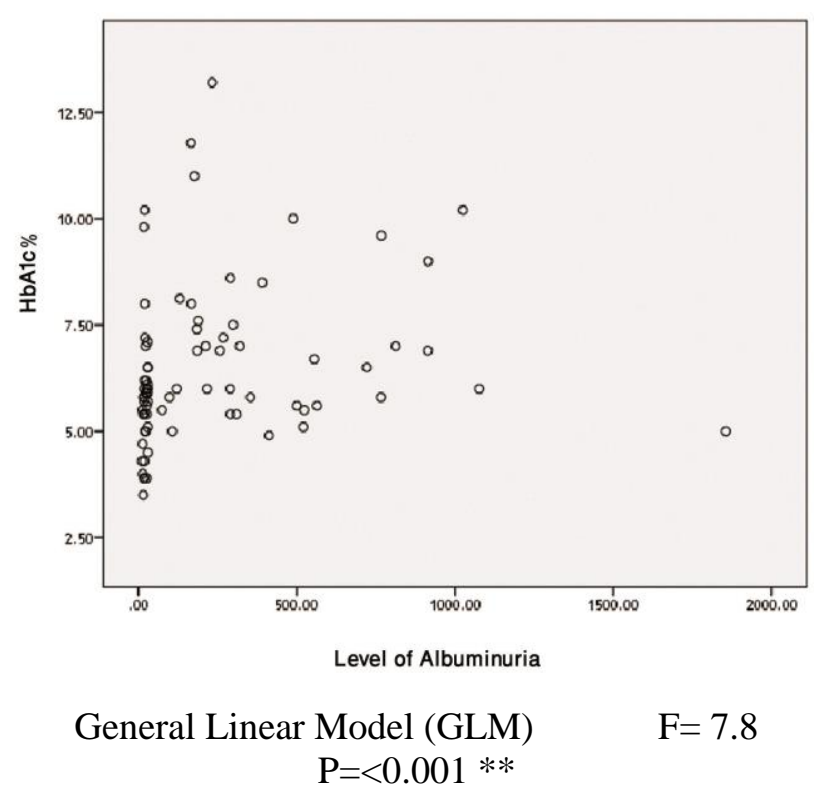

Figure (3): Relation between $\mathrm{HbA} 1 \mathrm{C}$ and Figure (4): Scattered diagram showing relation between outcome by GLM method. General Linear HbA1C and albuminuria Model 
Table (5): Shows the relation between serum lipid profile and albuminuria

$\begin{array}{cccccc}\begin{array}{c}\text { No albuminuria } \\ (\mathrm{n}=40)\end{array} & \begin{array}{c}\text { Microalbuminuria } \\ (\mathrm{n}=20)\end{array} & \begin{array}{c}\text { Macroalbuminuria } \\ (\mathrm{n}=20)\end{array}\end{array} \chi^{2} \quad \boldsymbol{p}$

\begin{tabular}{|c|c|c|c|c|c|c|c|c|}
\hline \multicolumn{9}{|l|}{ Triglycerides } \\
\hline $\mathrm{mg} / \mathrm{dl}$ & 28 & 70.0 & 6 & 30.0 & 9 & 45.0 & 9.4 & $>0.05$ \\
\hline $\begin{array}{c}(\mathrm{n}=37)>150 \\
\mathbf{m g} / \mathbf{d l}\end{array}$ & 12 & 30.0 & 14 & 70.0 & 11 & 55.0 & & \\
\hline LDL & & & & & & & & \\
\hline & 34 & 85.0 & 7 & 35.0 & 5 & 25.0 & 25.1 & $<0.001$ \\
\hline$(\mathrm{n}=34)>100 \mathrm{mg} / \mathbf{d l}$ & 6 & 15.0 & 13 & 65.0 & 15 & 75.0 & & \\
\hline
\end{tabular}

HDL

$(\mathrm{n}=8)<\mathbf{5 0} \mathbf{m g} / \mathbf{d l}$

for female $\&<40$

$\mathrm{mg} / \mathrm{dl}$ for male

$(\mathrm{n}=72)>$

$\begin{array}{cccccc}6 & 15.0 & 1 & 5.0 & 1 & 5.0 \\ 34 & 85.0 & 19 & 95.0 & 19 & 95.0\end{array}$

5.0

$2.2>0.05$

$50 \mathrm{mg} / \mathrm{dl}$ for

85.0

95.0

19

95.0

\section{female \& $>40 \mathrm{mg} / \mathrm{dl}$}

for male

LDL: low density of lipoproteinHDL: high density of lipoprotein

significant $\quad \mathrm{P}>0.05$ : non-significant

$\mathrm{P}<0.001:$ highly

Table (6): Relation between BMI and outcome in ACS patients admitted to ICU

\begin{tabular}{llcccccc}
\hline \hline & \multicolumn{2}{c}{ Not Complicated } & & \multicolumn{2}{c}{ Complicated } & & \multirow{2}{*}{$\chi^{2}$} \\
\cline { 2 - 5 } & No & \% & No & \% & & \\
\hline \hline BMI & & & & & & \\
$(\mathrm{n}=1)$ & Normal & 1 & 100.0 & 0 & 0.0 & 0.2 & $>0.05$ \\
$(\mathrm{n}=32)$ & Overweight & 15 & 46.8 & 17 & 53.2 & & \\
$(\mathrm{n}=47)$ & Obese & 29 & 61.0 & 18 & 38.3 & & \\
\hline \hline
\end{tabular}

BMI: body mass index $\quad \mathrm{P}>0.05$ : non-significant

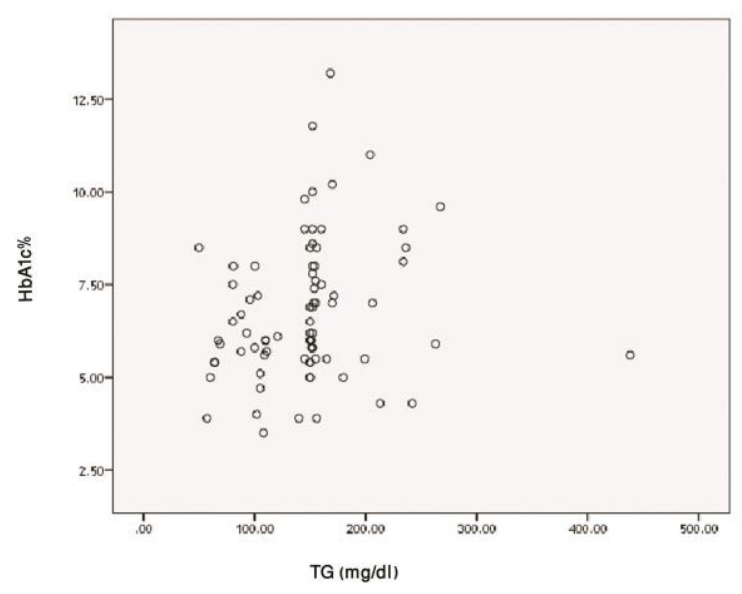

TG Pearson $r=-0.09$

$\mathrm{P}=\mathrm{NS}$

Figure (5): Showing correlation between $\mathrm{HbAlc}$ and Triglycerides

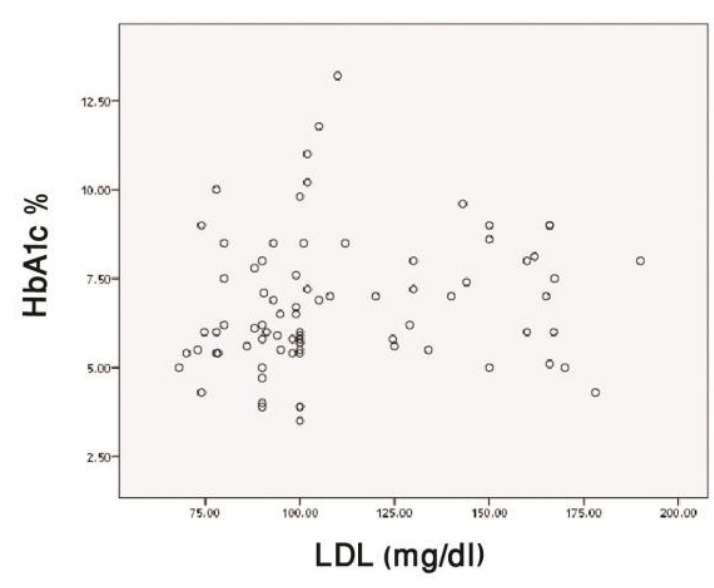

LDL Pearson $r=-0.16$ $\mathrm{P}=\mathrm{NS}$

Figure (6): Showing correlation between HbA1C and LDL 


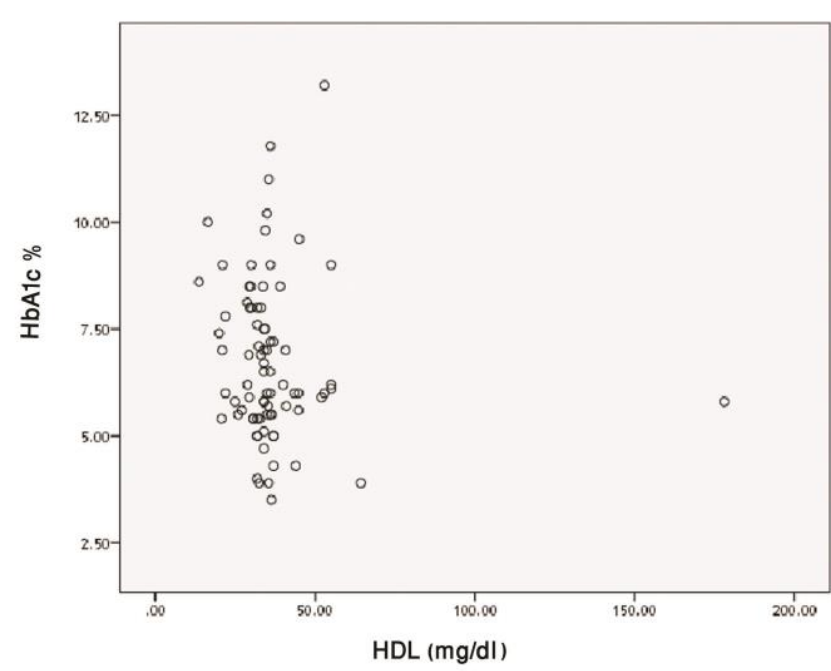

HDL Pearson $\quad r=-0.04 \quad P=N S$

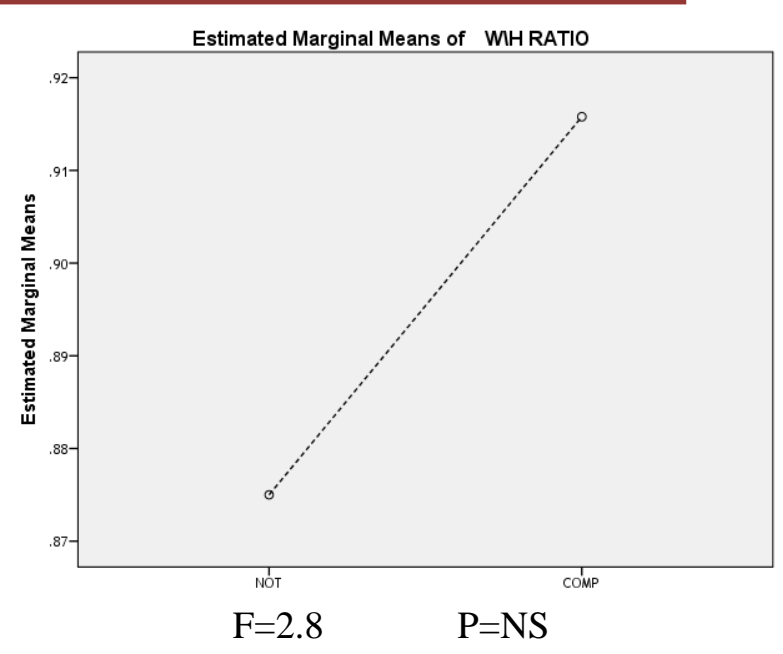

Figure (8): Relation between WH ratio and outcome by GLM method

Figure (7): Showing correlation between $\mathrm{HbA1C}$ and $\mathrm{HDL}$

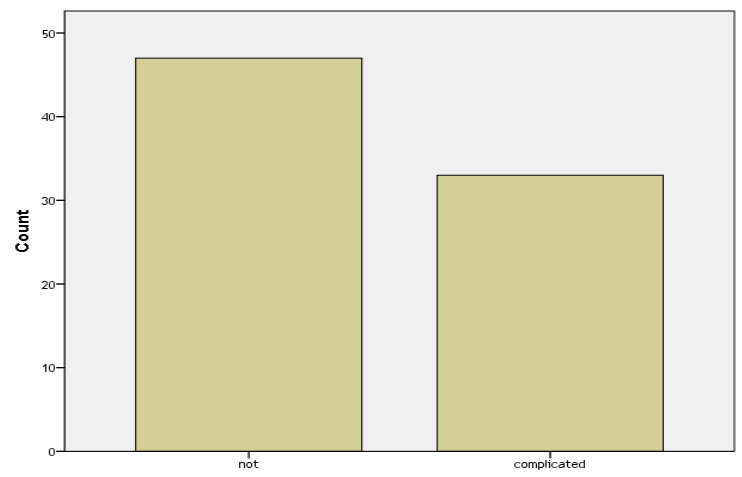

Figure (10): Showing the prevalence of complications in ACS patients admitted to ICU

\section{DISCUSSION}

Type 2 diabetes (T2D) is considered one of the major risk factors for ACS. Individuals with T2D are more likely to experience a coronary heart disease and have worse outcomes compared with non diabetic individuals (5).

ACS referred to unstable angina and myocardial infarction (MI) with or without ST-segment elevation which are life-threatening conditions that remain a source of high morbidity and mortality despite advances in treatment (6).

Intensive glucose control in T2D patients can reduce the risk of developing serious cardiovascular disease outcomes such as heart failure, arrhythmia, cardiogenic shock and cardiac arrest.

Evaluation of blood glucose control can be achieved by $\left(\mathrm{HbA}_{1 \mathrm{c}}\right)$ level measurement which is a convenient and well-known biomarker in clinical practice for average blood glucose concentrations over the preceding 2-3 months (7, 8).
The present study documented the effect of glycemic control on morbidity and mortality of ACS through measurement of $\left(\mathrm{HbA}_{1 \mathrm{c}}\right)$. This study showed that complications occurred more significantly with increased levels of $\mathrm{HbA1c}>7 \%$ in which percentage of complicated cases was $69.7 \%$ than that below $7 \%$ in which percentage of complicated cases was $30.3 \%$. So it was observed in the present study that non diabetics and good controlled type 2 diabetics have better outcome of CAD and lower percentage of complications than uncontrolled type 2 diabetics.

This observation correlates with Nishimura et al. which proved that a significant relation between having an $\mathrm{HbA} 1 \mathrm{c}$ level $\geq 6.5 \%$ and risk of $\mathrm{CAD}$ in Japanese patients (8). Also recommended that including lipid levels in the assessment model could help to identify subjects at high risk, Therefore, evaluating the relationship between $\mathrm{HbAlc}$ and CAD in patients with hypercholesterolemia is important to identify patients in a high-risk population (9). 
The present study correlates with Liu et al. who observed that elevated HbA1c levels predict increased risk of short and long term mortality in patients hospitalized with CAD. They also recommended that elevated $\mathrm{HbAlc}$ was associated with a higher risk of mortality in patients without recognized diabetes even after adjusting for other known risk factors (10).

This study also correlates with Olofsson et al. who proved that progressively increasing risk of $\mathrm{CAD}$ and total mortality with higher $\mathrm{HbAlc}$, and no risk increase at low $\mathrm{HbA} 1 \mathrm{c}$ levels even with longer diabetes duration, previous CVD or treatment with either insulin or OHDs. Patients achieving $\mathrm{HbA} 1 \mathrm{c}<7 \%$ showed reduced risk to have CAD (11).

The present study also correlates with Sahibzada et al, who proved that increased level of hyperglycemia expressed by higher levels of HbAlc associated with increase in the mortality. They also documented that Hyperglycemia associated with impaired left ventricular function and clinical evidence of left ventricular failure (12).

Diabetic dyslipidemia is characterized by elevated triglyceride levels, decreased high-density lipoprotein cholesterol levels, and elevated lowdensity lipoprotein cholesterol (LDL-C) levels. It is a well-recognized and modifiable risk factor for coronary heart disease. When diagnosis of dyslipidemia is established in T2D aggressive treatment should be started $(\mathbf{1 3}, \mathbf{1 4})$.

The present study documented that the prevalence of hypercholesterolemia is significantly more in diabetics than non diabetics $(p<0.05)$. On the other hand other parameters of lipid profile did not differ significantly between diabetics and non diabetics. This study also revealed that the complications occurred more significantly in patients with abnormal hypertriglyceridemia $(>150 \mathrm{mg} / \mathrm{dl}) 78.4 \%$ and abnormal levels of LDL $(>100 \mathrm{mg} / \mathrm{dl})$ 82.4\%. But there was non significant prevalence of complications among patients with abnormal HDL level $(<40 \mathrm{mg} / \mathrm{dl}$ for male, $<50 \mathrm{mg} / \mathrm{dl}$ for female). So it was observed in the present study that hyperlipidemia had deleterious effect on morbidity and mortality of ACS patients admitted to ICU.

This study correlates with Preis et al, who proved that the risk of developing cardiovascular disease is higher in diabetics than in non-diabetics. Compared with those without diabetes, individuals who eventually developed diabetes had higher levels of hypertension $(\mathrm{P}=0.003)$, high LDL $(\mathrm{p}=0.04)$, low HDL $(\mathrm{p}=0.0001)$, high triglycerides $(\mathrm{P}=0.04)$, and obesity $(\mathrm{p}<0.0001)$ at time points 30 years before diabetes diagnosis. After further adjustment for BMI, there was statistically significant for hypertension $(\mathrm{p}=0.02)$ and low HDL $(\mathrm{p}=0.01)$ remained statistically significant (15).

This study also correlates with Clausen et al, who proved that hypertriglyceridemia is a risk factor for CAD. They recommended that fasting lipid profile is a blood test that assesses the risk for developing cardiovascular complications by measuring levels of total cholesterol, high-density lipoprotein HDL, triglycerides, and low-density lipoprotein LDL (16).

The present study correlates with Nesto et al, who proved that among patients with $\mathrm{T} 2 \mathrm{D}$, insulin resistance, relative insulin deficiency, and obesity are associated with hypertriglyceridemia, low serum HDL cholesterol concentrations, and occasionally high serum LDL cholesterol and lipoprotein (a) values. They also recommended that any serum lipoprotein concentration abnormality brought diabetic patients to have more coronary disease than non diabetic patients (17).

This study also correlates with Betteridge, who documented that dyslipidemia, an important component of the insulin resistance syndrome and T2D, is strongly related to CVD risk. Statins have proved to be safe, very-well tolerated, and highly effective in reducing the levels of LDL cholesterol and Apo lipoprotein B .After that the next target of lipid-lowering therapy is to increase HDLcholesterol levels, which tend to be low in patients with T2D (18).

Albuminuria is a well-known predictor of poor renal outcomes in patients with type 2 diabetes and in essential hypertension. Albuminuria has also been shown more recently to be a predictor of cardiovascular outcomes in these populations (19, 20).

The present study documented that complications of ACS occurred more significantly in microalbuminuric patients $(70 \%)$ and macroalbuminuric patients (65\%) than non albuminuric patients (20\%). So it was observed in the present study that development of MA in type 2 diabetic patients worsen outcome of ACS patients admitted to ICU.

This study correlates with Weir, who proved that there is continuous positive relationship between urinary albumin excretion (UAE) and adverse clinical outcomes (21) and so MA is associated with an increased risk for all-cause and cardiovascular mortality (22).

The present study also correlates with Deveci et al, who proved that there is strong relationship 
between MA and the severity of CAD. They also demonstrated a positive relation between urine albumin/creatinine ratio (ACR) and extent of $\mathrm{CAD}$ both in the diabetic and non diabetic patients (4).

Basi et al. proved that the presence of albuminuria is a powerful predictor of renal and cardiovascular risk in patients with $\mathrm{T} 2 \mathrm{D}$ and hypertension. $\mathrm{He}$ also recommended that decreasing albuminuria with ACE inhibitor or ARB therapy can lead to improvement of the outcomes (2).

Aziz et al. examined coronary angiograms for extent of severe CAD (luminal narrowing >70\%) in patients without DM and so proved that, patients with MA have more severe angiographic detected coronary artery disease than those without MA (23).

With respect to our study, few studies focused on the relation between albuminuria and the outcome of ACS patients in ICU.

Jordanova-Laleva et al proved that the MA is a Considerable predictive factor in intra-hospital mortality coronary incidents and the death over longer periods after myocardial infarction. A considerable higher and heavier degree of coronary disease has been registered in patients with acute myocardial infarction (AMI) and MA than in patients with AMI but without MA (24).

Taskiran et al. documented that MA is strongly associated with an increased hazard of mortality in patients with AMI and increases the risk of death, independently of age and gender. Thus, MA is a very strong and robust risk indicator among patients with AMI (25).

Apostolovic et al proved that UACR measured during the first week after AMI is independently associated with increased long-term risk for inhospital and six-month mortality. On the basis of these results, they suggested that this measurement should be included in the routine clinical work up of patients with AMI (26).

This study documented that there is significant positive relation between albuminuria and $\mathrm{HbA} 1 \mathrm{c}$ level. Patients uncontrolled type 2 diabetics or recently discovered diabetics who showed higher levels of $\mathrm{HbAlc}$ also showed positive micro or macroalbuminuria. This correlates with Sheikh et al, who proved that early onset of MA in the selected community which could be due to poor glycaemic control (high HbA1c > 7\%) or heredity factors. Screening for MA and HbAlc test should be done in both newly and already diagnosed T2D patients as an early marker of renal dysfunction and glycaemic control (27).
On the contrary Afkhami-Ardekani et al, who proved that there is no statistical significant correlation between the prevalence of MA and the fasting blood sugar or HbA1c (28).

\section{CONCLUSION:}

There is a significant prevalence of albuminuria in diabetic patients in comparison with non diabetic patients. Complications including life threatening disorder as arrhythmia, heart failure, shock and cardiac arrest occurred more significantly in diabetic albuminuric patients with ACS during admission to ICU. Complications occurred more significantly in patients with abnormal lipid profile especially patients with hypertriglyceridemia or LDL > 100mg/dl.

\section{REFERENCES}

1. Sukhija R, Aronow WS, Kakar P, et al. Relation of microalbuminuria and coronary artery disease in patients with and without diabetes mellits. Am J. Cardiaol, 2006: 98(3): 279-81.

2. Basi S, Fesler P, Mimran A. et al. Microalbuminuria in type 2 diabetes and hypertension: A marker, treatment target, or innocent bystander? Diabetes Care 2008; 31 (2): S194-S201.

3. Mattock MB, Barnes DJ, Viberti G, et al. Microalbuminuria and coronary heart disease in NIDDM: an incidence study. Diabetes 1998; 47, (11): 1786-1792.

4. Deveci OS, Kabakci G, Tulumen E, et al. The relationship between microalbuminuria and the extent of coronary atherosclerosis. Angiology. 2010; 61(2):184-91.

5. Lago RM and Nesto RW. Type 2 diabetes and coronary heart disease: focus on myocardial infarction. Curr Diab Rep. 2009; 9(1):73-8.

6. Kolansky DM. Acute coronary syndromes: morbidity, mortality, and pharmacoeconomic burden Am J Manag Care. 2009; 15(2):S36-41.

7. Stratton IM, Adler AI, Neil HA, et al. Association of glycaemia with macrovascular and microvascular complications of type 2 diabetes (UKPDS 35): prospective observational study. BMJ. 2000; 3 21:405-12..

8. Nishimura $R$, Nakagami $T$, Sone $H$, et al. Relationship between hemoglobin A1c and cardiovascular disease in mild-to-moderate hypercholesterolemic Japanese individuals: subanalysis of a large-scale randomized controlled trial. Cardiovasc Diabetol. 2011; 10:58.

9. Chien KL, Lin HJ, Lee BC, et al. Prediction model for high glycated hemoglobin concentration among ethnic Chinese in Taiwan. Cardiovasc Diabetol. 21. Curr Diab Rep. 2009; 9(1):73-8.

10. Liu Y, Yang Y, Zhu J, et al: Prognostic Value of Hb A1C Cardiovasc Diabetol. 2011; 10:

11. Olofsson KE, Cederholm J, Nilsson PM, et al. New aspects of $\mathrm{HbAlc}$ as a risk factor for cardiovascular diseases in type 2 diabetes: an observational study 
from the Swedish National Diabetes Register (NDR). Journal of Internal Medicine 2010; 268, (5): 471-482.

12. Sahibzada P, Khan AA, Sahibzada WA. The impact of hyperglycaemia on morbidity and mortality of acute coronary syndromes and acute myocardial infarction. J Ayub Med Coll Abbottabad. 2009; 21(1):110-5.

13. Solano MP. and Goldberg RB. Clinical Diabetes 2006; 24, (1): 27-32.

14. Tonkin AM. and Chen L. Effects of combination lipid therapy in the management of patients with type 2 diabetes mellitus in the Action to Control Cardiovascular Risk in Diabetes (ACCORD) trial. Circulation, 2010; 122(8):850-2.

15. Preis SR, Pencina MJ, Mann DM, D'Agostino RB, et al. Early-adulthood cardiovascular disease risk factor profiles among individuals with and without diabetes in the framingham heart study. Diabetes Care. 2013; Abstract, In press.

16. Clausen P, Berglund L, Brunzell JD, Goldberg AC, et al. Evaluation and treatment of hypertriglyceridemia: an endocrine society clinical practice guideline. J. Clin. Endocrinol. Metab. 2012; 97 (9): 2969-89.

17. Nesto WR. Beyond low-density lipoprotein: addressing the atherogenic lipid triad in type 2 diabetes mellitus and the metabolic syndrome. Am J Cardiovasc Drugs. 2005; 5(6):379-87.

18. Betteridge DJ. Lipid control in patients with diabetes mellitus Nature Reviews Cardiology 2011; 8: 278-290.

19. Anavekar NS, Gans DJ, Berl T, et al. Predictors of cardiovascular events in patients with type 2 diabetic nephropathy and hypertension: a case for albuminuria. Kidney Int 2004; 1: S50-S55.

20. Ibsen H, Wachtell K, Olsen MH, et al. Does albuminuria predict cardiovascular outcome on treatment with losartan versus atenolol in hypertension with left ventricular hypertrophy? A LIFE substudy. J Hypertens 2004; 22:1805-1811.

21. Weir MR. University of Maryland Medical System CJASN 2007; 2 (3): 581-590.

22. Arnlov J, Evans JC, Meigs JB, et al. Low-grade albuminuria and incidence of cardiovascular disease events in nonhypertensive and nondiabetic individuals: The Framingham Heart Study. Circulation 2005; 112:969-975.

23. Aziz F, Penupolu S, Doddi S, et al. Microalbuminuria as predictor of severity of coronary artery disease in non-diabetic patients: The Internet Journal of Cardiology. 2010; 9 (1): ISSN: $1528-834 \mathrm{X}$.

24. Jordanova-Laleva P, Grigorov F, Petkova1 V, et al. The level of microalbumin excretion and its short term prognosis in acute myocardial infarction. Trakia Journal of Sciences, 2007; 5, (1):6-9.

25. Taskiran M, Iversen A, Klausen K, Jensen GB, Jensen JS. The association of microalbuminuria with mortality in patients with acute myocardial infarction. A ten-year follow-up study. Heart Int. 2010; 5(1):e2.

26. Apostolovic S, Stanojevic D, Djordjevic V, Tomasevic RJ, et al. Prognostic significance of microalbuminuria in patients with acute myocardial infarction. Clin Lab. 2011; 57(3-4):229-35.

27. Sheikh SA, Baig JA, Iqbal T, et al. Prevalence of microalbuminuria with relation to glycemic control in type-2 diabetic patients in Karachi. J Ayub Med Coll Abbottabad. 2009; 21(3):83-6.

28. Afkhami-Ardekani M, Modarresi M, Amirchaghmaghi E. Prevalence of microalbuminuria and its risk factors in type 2 diabetic patients. Indian J Nephrol. 2008; 18:112-7. 


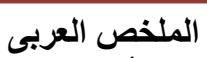

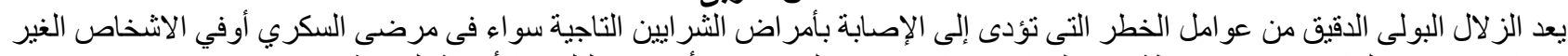

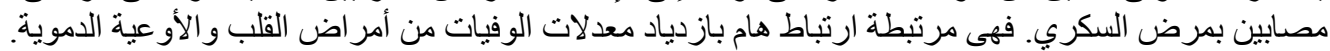

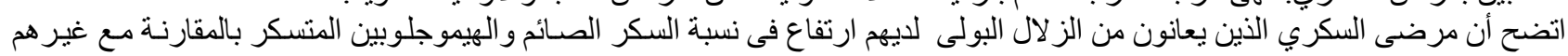

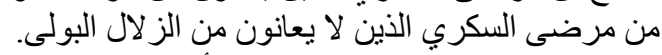

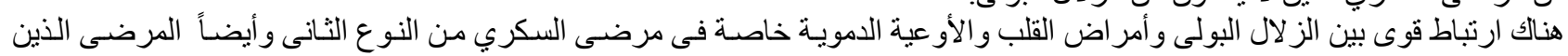

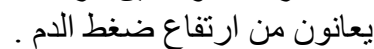

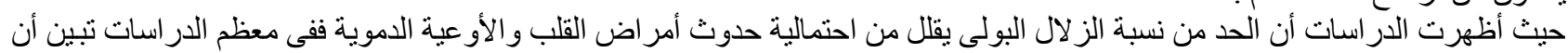

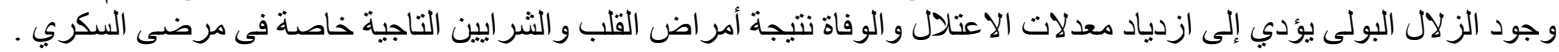

الهزف من البحث

در اسة معدلات البحثة الاعتلال فى مرضى السكري الذين بعانون متلازمة الثر ايين التاجية و علاقتها بالز لال البولى.

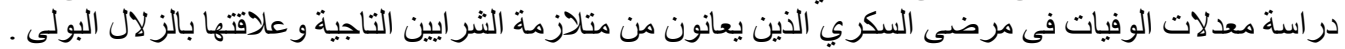

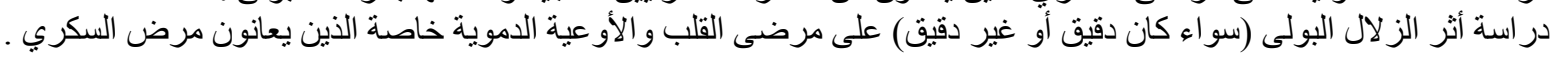

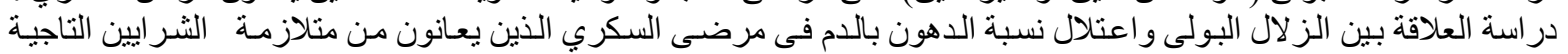

والحادة.

ولقد شملت هذه الار اسة م ـ 1 مريضاً:

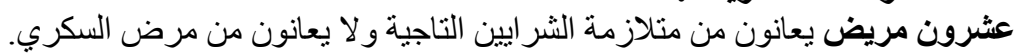

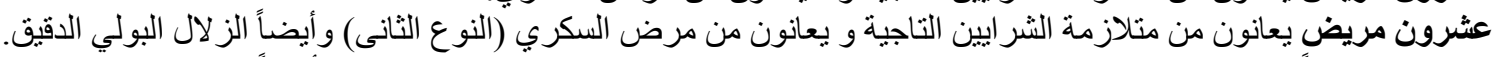

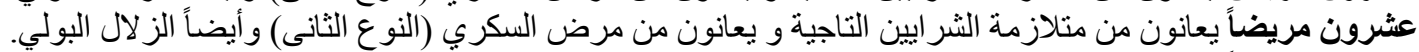

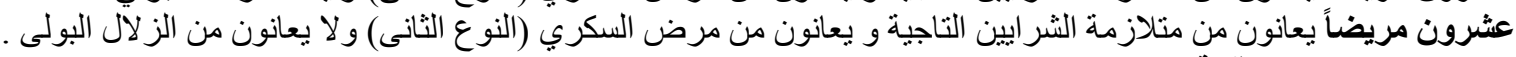
وقد أجريت عليهم الفحوصنات الآتية:

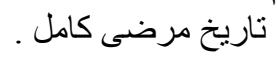
فحص إكلينيكي شامل. تمان.

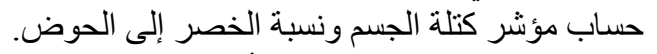
وظائف كبد وكلى ونسبة اليورك كلة أسيد بالدم.

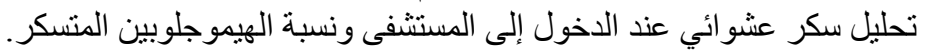

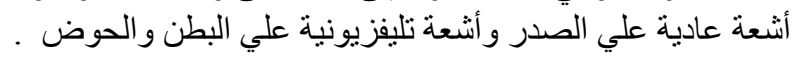
رسم قلب كهربائي نسبة و إنزيمات القلب بالبة والدة.

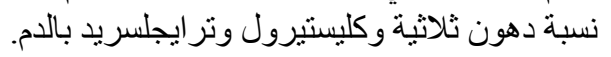

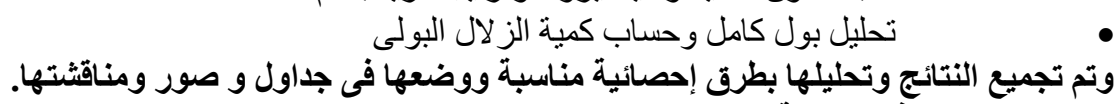

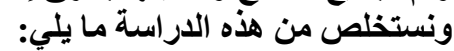

هناك انتشار كبير لارتفاع لـاع نسبة الكوليسترول بالدم فى مرضى السكري مقارنةً مع المرضى الغير مصابين بمرض السكري.

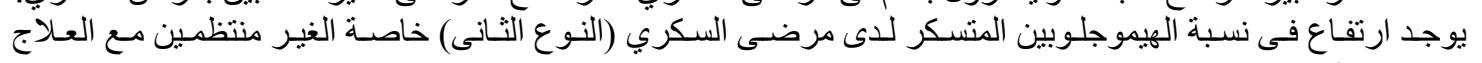
( والمرضى ذو تاريخ مرضي قصبير.

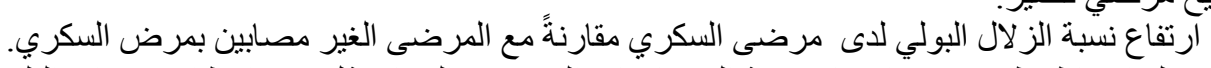

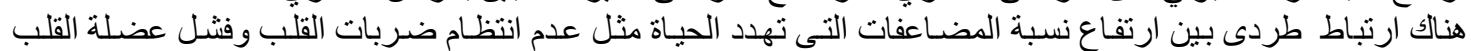

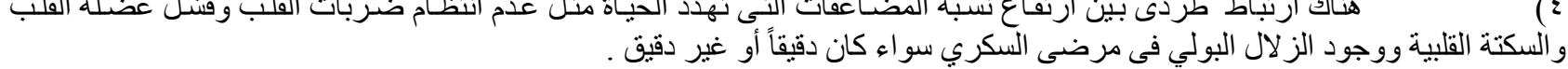

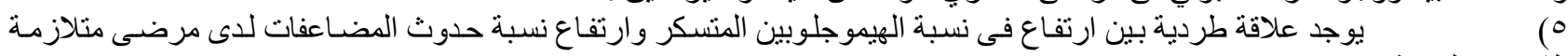

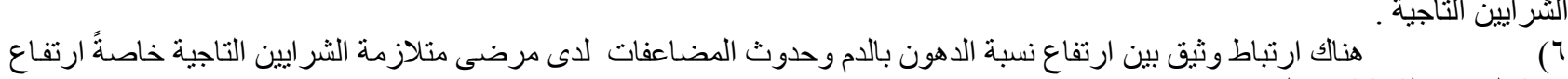
نسبة الدهون الثلاثية في الدم. 